\title{
Activated Platelets Signal Chemokine Synthesis by Human Monocytes
}

\author{
Andrew S. Weyrich, ${ }^{* \|}$ Mark R. Elstad, ${ }^{\star \S \|}$ Rodger P. McEver, ${ }^{\ddagger \ddagger}$ Thomas M. Mclntyre, ${ }^{*|| \star \star}$ Kevin L. Moore, ${ }^{\ddagger \ddagger}$ James H. Morrissey, ${ }^{\ddagger \ddagger}$ \\ Stephen M. Prescott, ${ }^{* \neq\|\|}$ and Guy A. Zimmerman*\| \\ ${ }^{*}$ The Nora Eccles Harrison Cardiovascular Research and Training Institute, ${ }^{\ddagger}$ Eccles Program in Human Molecular Biology and Genetics, \\ ${ }^{\S}$ Department of Medicine, Veterans Affairs Medical Center, and the Departments of ${ }^{\|}$Internal Medicine, "Biochemistry, and **Pathology, \\ University of Utah Health Sciences Center, Salt Lake City, Utah 84112; and the ${ }^{\ddagger}$ W.K. Warren Medical Research Institute and the \\ Departments of Medicine, Biochemistry, Molecular Biology, and Pathology, University of Oklahoma Health Sciences Center and the \\ Cardiovascular Biology Research Program, Oklahoma Medical Research Foundation, Oklahoma City, Oklahoma 73104
}

\begin{abstract}
Human blood monocytes adhere rapidly and for prolonged periods to activated platelets that display P-selectin, an adhesion protein that recognizes a specific ligand on leukocytes, P-selectin glycoprotein-1. We previously demonstrated that $\mathrm{P}$-selectin regulates expression and secretion of cytokines by stimulated monocytes when it is presented in a purified, immobilized form or by transfected cells. Here we show that thrombin-activated platelets induce the expression and secretion of monocyte chemotactic protein-1 and IL- 8 by monocytes. Enhanced monokine synthesis requires engagement of P-selectin glycoprotein-1 on the leukocyte by P-selectin on the platelet. Secretion of the chemokines is not, however, directly signaled by P-selectin; instead, tethering of the monocytes by $\mathrm{P}$-selectin is required for their activation by RANTES (regulated upon activation normal $T$ cell expressed presumed secreted), a platelet chemokine not previously known to induce immediate-early gene products in monocytes. Adhesion of monocytes to activated platelets results in nuclear translocation of p65 (RelA), a component of the NF- $\kappa$ B family of transcription factors that binds $\kappa B$ sequences in the regulatory regions of monocyte chemotactic protein-1, IL-8, and other immediate-early genes. However, expression of tissue factor, a coagulation protein that also has a $\kappa B$ sequence in the $5^{\prime}$ regulatory region of its gene, is not induced in monocytes adherent to activated platelets. Thus, contact of monocytes with activated platelets differentially affects the expression of monocyte products. These experiments suggest that activated platelets regulate chemokine secretion by monocytes in inflammatory lesions in vivo and provide a model for the study of gene regulation in cell-cell interactions. (J. Clin. Invest. 1996. 97: 1525-1534.) Key words: P-selectin • RANTES • signaling • monocyte chemotactic protein-1 $\cdot \mathrm{NF}-\kappa \mathrm{B}$
\end{abstract}

Address correspondence to Guy A. Zimmerman, M.D., University of Utah, CVRTI, Building 500, Salt Lake City, Utah 84112. Phone: 801581-8183; FAX: 801-581-3128.

Received for publication 30 October 1995 and accepted in revised form 21 December 1995.

J. Clin. Invest.

(c) The American Society for Clinical Investigation, Inc. 0021-9738/96/03/1525/10 \$2.00

Volume 97, Number 6, March 1996, 1525-1534

\section{Introduction}

Myeloid leukocytes adhere to other cells and to extracellular matrix $(\mathrm{ECM})^{1}$ via surface adhesion molecules (1). In human monocytes, a myeloid subset, engagement of adhesion molecules not only tethers the leukocyte but also induces intracellular signals, or modifies signals delivered through surface receptors $(2,3)$. Adhesion of monocytes to ECM proteins via $\beta 1$ integrins elicits specific patterns of messenger RNA for immediate-early (IE) gene products. When stimulated with a "second signal" such as bacterial LPS, monocytes translate these messages and synthesize proteins that influence inflammatory responses (4). We recently reported a mechanism for regulation of monocyte gene expression when these leukocytes adhere to a protein on the surface of endothelial cells, rather than ECM proteins (3). Adhesion of monocytes to purified P-selectin, a tethering molecule expressed by stimulated endothelial cells and platelets (5), resulted in nuclear translocation of a transcription factor, NF-кB $(6,7)$, and secretion of NF$\kappa \mathrm{B}-$ dependent cytokines when the monocytes were simultaneously exposed to platelet-activating factor (PAF) (3). The receptor for PAF is a member of the serpentine, G-proteinlinked family (8) that can mediate NF- $\mathrm{B}$ activation when it is transfected into cells (9). In our studies, PAF was a weak agonist for NF-кB-dependent responses in monocytes unless they were adherent to P-selectin (3). This finding, based on experiments in which $\mathrm{P}$-selectin was immobilized in purified form or presented by transfected cells (3), suggests that adhesion of monocytes to P-selectin integrates or amplifies signals delivered by the PAF receptor and, perhaps, by other receptors.

In vivo, activated endothelial cells and platelets translocate P-selectin to the surface from intracellular storage granules, and monocytes adhere to both cell types (10-12). While endothelial cells express P-selectin on their surfaces transiently under most physiologic conditions, P-selectin on the surfaces of platelets is relatively stable and can sustain platelet-monocyte contact for hours (13). However, it is not known whether binding of P-selectin glycoprotein ligand-1 (PSGL-1) $(5,14-16)$ on the monocyte to $\mathrm{P}$-selectin presented on activated platelets influences nuclear signaling or chemokine generation by the leukocyte. This issue is important because these cells adhere to

1. Abbreviations used in this paper: $\mathrm{CHO}$, Chinese hamster ovary; ECM, extracellular matrix; IE, immediate-early; MCP-1, monocyte chemotactic protein-1; PAF, platelet-activating factor; PSGL-1, P-selectin glycoprotein ligand-1; RANTES, regulated upon activation normal T cell expressed presumed secreted; rhRANTES, recombinant human RANTES; TF, tissue factor. 
one another in numerous inflammatory and thrombotic disorders. Leukocytes accumulate around platelet-rich thrombi at sites of hemorrhage (17) and platelets colocalize with mononuclear phagocytes during the early stages of atherosclerosis (18). Platelet-leukocyte aggregates are also found in the circulation and at the vascular wall after exposure to oxidized LDL or cigarette smoke $(19,20)$ and during thrombus formation (21). Neutralization of P-selectin diminishes these interactions. Identification of functional alterations that are induced when monocytes bind to P-selectin on the surface of activated platelets may be required to understand inflammatory responses that accompany concomitant recruitment of platelets and leukocytes. Here we demonstrate that activated platelets induce secretion of monocyte chemotactic protein-1 (MCP-1) and IL- 8 by monocytes, and that adhesion via P-selectin is required for these responses. Rather than directly triggering these events, P-selectin acts in concert with RANTES (regulated upon activation normal $\mathrm{T}$ cell expressed presumed secreted), a chemokine that is stored and released by activated platelets that was not previously known to induce monokine synthesis.

\section{Methods}

Reagents. HBSS and M199 (phenol red free) were from Whittaker M.A. Bioproducts (Walkersville, MD), and HSA (25\%) was from Miles Laboratories, Inc. (Elkhart, IN). Fatty acid-free BSA, hirudin, LPS, PGE-1, polymyxin B sulfate, and thrombin were from Sigma Chemical Co. (St. Louis, MO). FCS was from Hyclone Inc. (Logan, UT).

P-Selectin was purified from human platelets and characterized as previously described (22). $\mathrm{F}\left(\mathrm{ab}^{\prime}\right)_{2}$ fragments of $\mathrm{mAb} \mathrm{G} 1$ and $\mathrm{S} 12$, which are directed against P-selectin (23) and have very low endotoxin contamination $(<0.01$ endotoxin $\mathrm{U} / \mathrm{ml})$, were generously provided by John Grayeb of Centocor Inc. (Malvern, PA). The monovalent $\mathrm{Fab}^{\prime}$ fragments of mAb PL1 and PL2, which are directed against PSGL-1, were purified and characterized as recently described (16). Recombinant human MCP-1, recombinant human IL-8, and polyclonal rabbit anti-human MCP-1 were from Genzyme Corp. (Cambridge, MA). Recombinant human RANTES was from Biosource International (Camarillo, CA). Anti-human IL-8 and neutralizing antibodies against RANTES, each containing endotoxin levels that were $<10 \mathrm{ng} / \mathrm{mg}$ as measured by the manufacturer, were from $\mathrm{R} \& \mathrm{D}$ Systems (Minneapolis, MN). Antibodies against p65 (RelA) were from Santa Cruz Biotechnology, Inc. (Santa Cruz, CA). The anti-tissue factor (TF) antibody, TF8-5G9, has been previously described (24).

Cell isolation. Human peripheral blood monocytes were isolated from healthy donors as described (25). Mononuclear cells were separated from whole blood by density gradient centrifugation, and monocytes were further purified (90-95\%) by countercurrent elutriation (25).

Platelets were isolated using the methods of Hamburger and McEver (26). In brief, human blood was drawn into acid-citrate-dextrose (ACD) $(7 \mathrm{ml} \mathrm{ACD} / 42 \mathrm{ml}$ of blood) and was centrifuged (200 $\mathrm{g}$ for $20 \mathrm{~min}$ ) to obtain platelet-rich plasma. Platelet-rich plasma was recentrifuged (500 $\mathrm{g}$ for $20 \mathrm{~min}$ ) in the presence of $100 \mathrm{nM}$ PGE-1. The supernatant was discarded and $50 \mathrm{ml}$ of Pipes/saline/glucose (5 mM Pipes, $145 \mathrm{mM} \mathrm{NaCl}, 4 \mathrm{mM} \mathrm{KCl}, 50 \mu \mathrm{M} \mathrm{Na}_{2} \mathrm{HPO}_{4}, 1 \mathrm{mM} \mathrm{MgCl}{ }_{2}-$ $6 \mathrm{H}_{2} \mathrm{O}$, and $5.5 \mathrm{mM}$ glucose), containing $100 \mathrm{nM}$ of PGE-1, was used to resuspend the platelet pellet. The platelet suspension was centrifuged (500 $\mathrm{g}$ for $20 \mathrm{~min}$ ), the supernatant was discarded, and the platelet pellet was resuspended in $\mathrm{Ca}^{2+}$ - and $\mathrm{Mg}^{2+}$-free HBSS.

Studies of platelet-monocyte interactions. At the beginning of each experiment, platelets were pelleted by centrifugation $(500 \mathrm{~g}$ for $20 \mathrm{~min})$ and resuspended $\left(10^{8}\right.$ platelets $/ \mathrm{ml}$ unless designated otherwise) in serum-free M199 medium containing $10 \mu \mathrm{g} / \mathrm{ml}$ of polymyxin
B sulfate (except in experiments with LPS-stimulated monocytes). The suspensions were placed in sterile polypropylene round-bottomed centrifuge tubes (Becton Dickinson Labware, Lincoln Park, $\mathrm{NJ}$ ) in the absence or presence of $0.25 \mathrm{U} / \mathrm{ml}$ of thrombin. After 30 min, hirudin $(1 \mathrm{U} / \mathrm{U}$ thrombin) was added to inactivate thrombin (27). Monocytes $\left(10^{6} / \mathrm{ml}\right)$ then were added to the platelet suspensions, and the mixture was gently rocked for $18 \mathrm{~h}$ at $37^{\circ} \mathrm{C}$ unless otherwise indicated. In some experiments, an aliquot containing $10^{5}$ monocytes $\left(10^{7}\right.$ platelets) was removed at the end of the incubation period for analysis of TF expression. The remaining cell suspensions were centrifuged at 15,000 $\mathrm{g}$ for $10 \mathrm{~min}$, and the cell-free supernatants were collected and stored at $-70^{\circ} \mathrm{C}$ for subsequent chemokine analysis. In selected studies, antibodies were added to the platelet or monocyte suspensions $5 \mathrm{~min}$ before the cells were coincubated.

Studies of monocytes adherent to immobilized P-selectin and to transfected cells that express $P$-selectin. Our assays of monocyte adhesion to immobilized P-selectin and control proteins, and to transfected and control cells, have been described, as have our assays of functional responses of adherent monocytes $(3,28)$. Briefly, flat-bottomed 96-well microtiter plates (for TF analysis; Costar Corp., Cambridge, MA) or 16-mm plates (for cytokine analysis; Nunclon, Denmark) were incubated overnight at $4^{\circ} \mathrm{C}$ with HBSS containing $10 \mu \mathrm{g} /$ $\mathrm{ml}$ of HSA or P-selectin $(1,2,5$, or $10 \mu \mathrm{g} / \mathrm{ml})$. The plates were blocked with HSA $(10 \mathrm{mg} / \mathrm{ml}$ in HBSS $)$ for $4 \mathrm{~h}$ at $25^{\circ} \mathrm{C}$. The plates were washed twice with HBSS $-0.05 \%$ Tween- 20 and three times with HBSS. Monocytes $\left(10^{6} / \mathrm{ml}\right)$, resuspended in serum-free M199 medium containing polymyxin B sulfate $(10 \mu \mathrm{g} / \mathrm{ml})$, were added to the coated surfaces and maintained at $37^{\circ} \mathrm{C}$ for the indicated times. We previously showed that monocytes adhere specifically to immobilized P-selectin under these conditions $(3,28)$. After incubation the medium overlaying the monocytes was aspirated and centrifuged at $15,000 \mathrm{~g}$ for 10 min, and the cell-free supernatants were stored at $-70^{\circ} \mathrm{C}$ for subsequent analysis of chemokines. In selected studies, monocytes were allowed to adhere to Chinese hamster ovary $(\mathrm{CHO})$ cells transfected with cDNA for P-selectin or to wild-type CHO cells (29), and assays were conducted as described above. In parallel experiments, TF was measured in the 96-well plates as described below.

TF assays. TF activity was measured using the two-stage amidolytic assay described by Drake et al. (30). In selected experiments, the results from this method were verified using minor modifications of a single-stage amidolytic assay (31) or a single-stage plasma coagulation assay (32). Negative (HBSS) and positive (LPS, $100 \mathrm{ng} / \mathrm{ml}$ ) controls were included routinely. The assays were proportional to the monocyte numbers in this range, and activity was inhibited by TF8$5 \mathrm{G} 9$, an antibody that blocks TF activity (not shown).

Cytokine and PAF assays. Concentrations of MCP-1 were measured by ELISA as described previously (3), and concentrations of RANTES and IL-8 were measured using the same ELISA procedure. All ELISAs were specific and did not cross-react with one another or with other cytokines or chemokines (GM-CSF, TNF- $\alpha$, or MIP-1 $\alpha$ ). $\mathrm{PAF}$ accumulation was determined by quantitation of the incorporation of $\left[{ }^{3} \mathrm{H}\right]$ acetate into $\left[{ }^{3} \mathrm{H}\right]$ acetyl-PAF $(28)$.

Immunocytochemical detection of p65 (RelA) in platelet-monocyte suspensions. Immunolocalization of p65 (RelA) was determined in platelet-monocyte suspensions using methods previously described for monocytes adherent to purified, immobilized P-selectin (3), with minor modifications. Monocytes were incubated in suspension alone or with platelets as described above. After $2 \mathrm{~h}$, the cell suspensions were spun onto glass slides using a centrifuge (Cytospin 2; Shandon Inc., Pittsburgh, PA) and immediately fixed with $4 \%$ paraformaldehyde at $25^{\circ} \mathrm{C}$ for $20 \mathrm{~min}$. After this fixation procedure, immunocytochemical analysis was conducted using a rabbit polyclonal IgG against p65 or rabbit $\operatorname{IgG}(1 \mathrm{mg} / \mathrm{ml})$ in PBS and $1 \%$ goat serum. The peroxidase-stained monocytes were viewed with a light microscope (Carl Zeiss, Inc., Thornwood, NY) using Nomarski interference optics. We previously showed that this assay detects shifts of p65 from the cytoplasm of resting monocytes to the nucleus upon cellular activation. Translocation of the p50/p65 complex (NF-kB) mea- 
sured by electrophoretic mobility shift assay parallels nuclear accumulation of the anti-p65 antibody by immunocytochemical analysis (3).

Expression of data and statistics. Experiments were performed at least two times with cells from different donors, and all assays were performed in duplicate. The means $\pm S E$ from all experiments are presented where indicated. Representative experiments are shown in some cases because we observed significant interassay variation in cytokine release by monocytes from different donors. Adherence assays were rounded to the nearest percentage. ANOVA was used to determine differences among the groups. If significant differences were found, a Newman-Keuls post hoc procedure was used to determine the location of the difference. $P<0.05$ was considered statistically significant.

\section{Results}

Activated platelets adhere to monocytes and induce MCP-1 secretion. Consistent with previous reports, we found that mixing monocytes with platelets that were activated by thrombin resulted in adhesion between the two cells. Activated platelets formed "rosettes" around the monocytes, and platelet-monocyte rosettes were routinely observed throughout the cell suspension (see below). Many of the cell clusters contained several monocytes. We then determined whether the adherent platelets induced chemokine release by monocytes, using MCP-1 as the marker (Fig. $1 A$ ). Monocytes did not release MCP-1 under basal conditions (not shown), and there was little or no secretion of MCP-1 $(<0.1 \mathrm{ng} / \mathrm{ml})$ when monocytes were incubated without stimulation. Similarly, direct addition of thrombin inactivated with hirudin did not induce MCP-1 secretion, consistent with a previous report (33). There was a small increase in MCP-1 production (Fig. $1 A$ ) in experiments where monocytes were incubated with unstimulated platelets. These small increases may have been due to spontaneous activation of the platelets with longer ex vivo incubation periods (34). In contrast, platelets activated by thrombin induced significant $(P<0.01)$ release of MCP-1 compared with levels found when monocytes were incubated in the absence of platelets or with unactivated platelets. This increase was seen in seven independent experiments, although the magnitude varied among donors (range $0.65-9.80 \mathrm{ng} / \mathrm{ml}$ of MCP-1). The secretion of MCP-1 was dependent on time (Fig. $1 \mathrm{~B}$ ) and platelet concentration, where platelet-monocyte ratios of 100:1 (platelets/monocyte) yielded maximal cytokine secretion (not shown).

Adhesion of activated platelets via P-selectin is necessary for maximal MCP-1 release by monocytes. We assessed thrombinactivated platelets by flow cytometry and found that there was increased surface expression of P-selectin compared with unactivated platelets, as previously reported $(10,26,35)$. Further, removal of $\mathrm{Ca}^{2+}$ from the incubation buffer inhibited the adhesion of activated platelets to monocytes and also blocked the secretion of MCP-1 (not shown), consistent with a selectinmediated effect (11). These results suggested that P-selectin was required for the platelet-induced monokine secretion. Therefore, we examined the effect of antibodies to P-selectin, and to its ligand, PSGL-1, on MCP-1 secretion when activated platelets interact with monocytes.

Neutralization of P-selectin inhibits MCP-1 release. The $\mathrm{F}\left(\mathrm{ab}^{\prime}\right)_{2}$ fragment of a blocking mAb to P-selectin, G1 (23), significantly attenuated MCP-1 secretion in platelet-monocyte mixtures (Fig. 2). In contrast, the $\mathrm{F}\left(\mathrm{ab}^{\prime}\right)_{2}$ fragment of $\mathrm{mAb}$ S12, a nonblocking control antibody that also recognizes
A

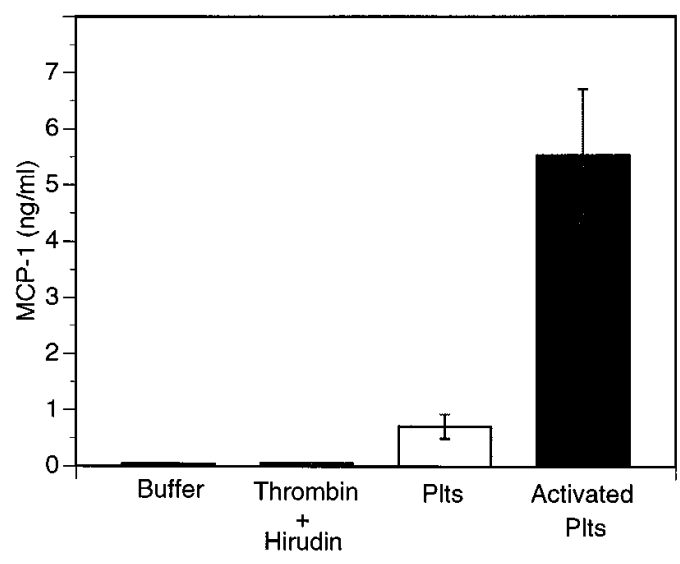

B

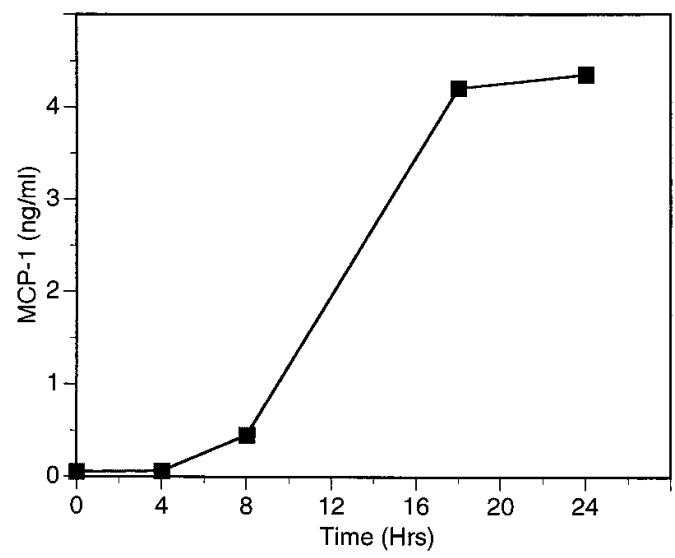

Figure 1. Activated platelets stimulate MCP-1 secretion by monocytes. (A) Activation of platelets (Plts) is required for maximal MCP-1 release. Monocytes $\left(10^{6} / \mathrm{ml}\right)$ were incubated with buffer (M199), with thrombin $(0.25 \mathrm{U} / \mathrm{ml})$ and hirudin $(1 \mathrm{U} / \mathrm{U}$ thrombin), with unactivated platelets $\left(10^{8} / \mathrm{ml}\right)$, or with activated platelets $\left(10^{8} / \mathrm{ml}\right.$ activated with thrombin, followed by addition of hirudin) as described in Methods. After $18 \mathrm{~h}, \mathrm{MCP}-1$ in cell-free supernatants was measured by ELISA. The bars indicate the mean \pm SE of seven experiments. $(B)$ Temporal response. Thrombin-activated platelets $\left(10^{8} / \mathrm{ml}\right)$ were added to $10^{6}$ monocytes $/ \mathrm{ml}$, and MCP- 1 release was measured at 0,4 , 8,18 , and $24 \mathrm{~h}$. Data are the means of duplicate determinations from one experiment that is representative of two.

P-selectin, had no effect (Fig. 2). G1, but not S12, also inhibited platelet-monocyte rosetting, as previously reported (26). These experiments indicated that adhesion of platelets to monocytes via $\mathrm{P}$-selectin is required for maximal MCP-1 release.

Neutralization of PSGL-1 inhibits MCP-1 secretion. Although P-selectin binds to a variety of natural and synthetic structures $(5,36,37)$, a preferred ligand is PSGL-1, a sialomucin that is constitutively present on monocytes and other myeloid leukocytes $(14-16,38)$. PL1, a previously described mAb, recognizes PSGL-1 and blocks its binding to P-selectin (16). Because PSGL-1 is present on certain leukocyte subsets but does not bind P-selectin (for review see reference 5), we first examined the effects of PL1 on adhesion of monocytes to transfected cells that display P-selectin. We found that PL1 inhibits monocyte adhesion to $\mathrm{CHO}$ cells expressing P-selectin, 


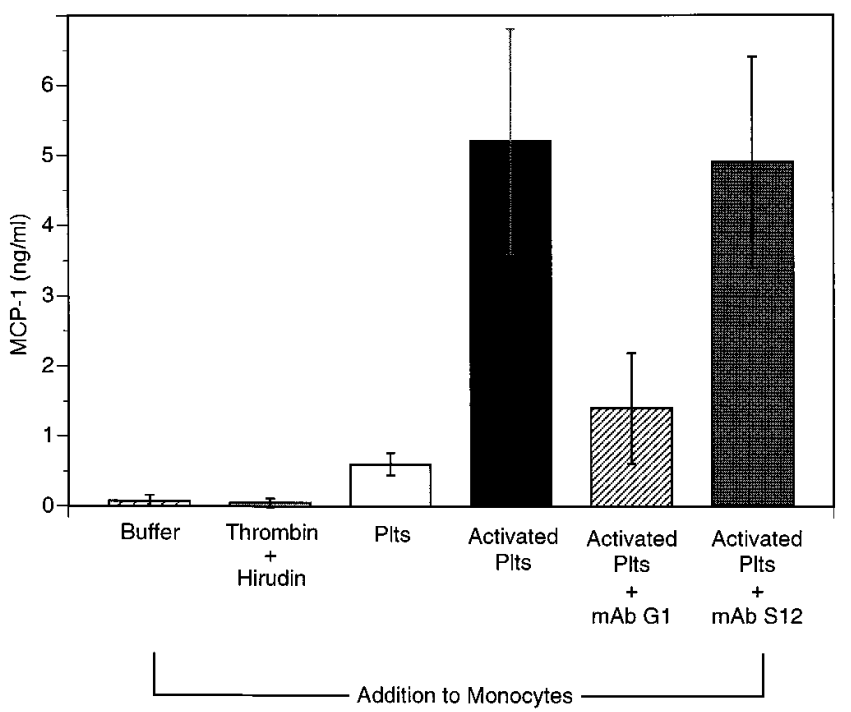

Figure 2. An antibody against $\mathrm{P}$-selectin inhibits MCP-1 release by monocytes incubated with activated platelets (Plts). Platelets $\left(10^{8} / \mathrm{ml}\right)$ were activated with thrombin as described in Fig. 1.5 min before the addition of monocytes $\left(10^{6} / \mathrm{ml}\right), \mathrm{F}\left(\mathrm{ab}^{\prime}\right)_{2}$ fragments of mAb G1 $(10 \mu \mathrm{g} /$ $\mathrm{ml}$ ), which blocks P-selectin-mediated adhesion, or the $\mathrm{F}\left(\mathrm{ab}^{\prime}\right)_{2}$ fragments of mAb S12 $(10 \mu \mathrm{g} / \mathrm{ml})$, which binds P-selectin but does not alter adhesive interactions, were added to the platelet suspensions. After $18 \mathrm{~h}, \mathrm{MCP}-1$ secretion by monocytes was quantitated. This figure represents the mean $\pm \mathrm{SE}$ of five experiments that showed decreased $\mathrm{MCP}-1$ secretion in the presence of G1.

whereas PL2, a nonblocking $\mathrm{mAb}$ that recognizes PSGL-1 (16), does not (not shown). Thus, PSGL-1 on monocytes is functional and mediates adhesive interactions. We next examined these antibodies in platelet-monocyte interactions. We found that the Fab' fragment of mAb PL1 inhibited plateletmonocyte rosetting (not shown) and MCP-1 secretion by monocytes (Fig. 3). The Fab' fragment of PL2 did not inhibit these responses (not shown).

Activated platelets induce translocation of $N F-\kappa B$ in monocytes. Nuclear translocation of NF-кB, a heterodimeric transcription factor composed of proteins of the Rel family $(6,7)$, is required for MCP-1 expression (39). The p50-p65 heterodimer, commonly known as NF-кB, is located in the cytoplasm of unstimulated monocytes; with appropriate stimulation, it is rapidly translocated to the cell nucleus, where it binds to $\kappa \mathrm{B}$ sequences in the promoter and enhancer regions of several IE genes $(3,7)$. We first examined the distribution of $\mathrm{NF} \kappa \mathrm{B}$ in resting monocytes and in monocytes incubated with activated platelets using an electromobility shift assay (3). Activated platelets induced nuclear accumulation of NF- $\mathrm{NB}$ in this analysis (not shown). We then examined the distribution of $\mathrm{NF}-\kappa \mathrm{B}$ in platelet-monocyte interactions using an antibody directed against the p65 subunit (RelA). In suspensions containing monocytes alone, $\mathrm{p} 65$ was primarily localized in the cell cytoplasm (Fig. $4 A$ ). The addition of unactivated platelets to monocyte suspensions caused no change, or a small increase, in p65 nuclear localization (Fig. $4 \mathrm{~B}$ ). However, when activated platelets were added, there was intense staining of p65 in the nuclei of monocytes (Fig. $4 \mathrm{C}$ ), and monocyte nuclei appeared more condensed. As described above, platelets readily adhered and rosetted around the monocytes, and aggregates con-

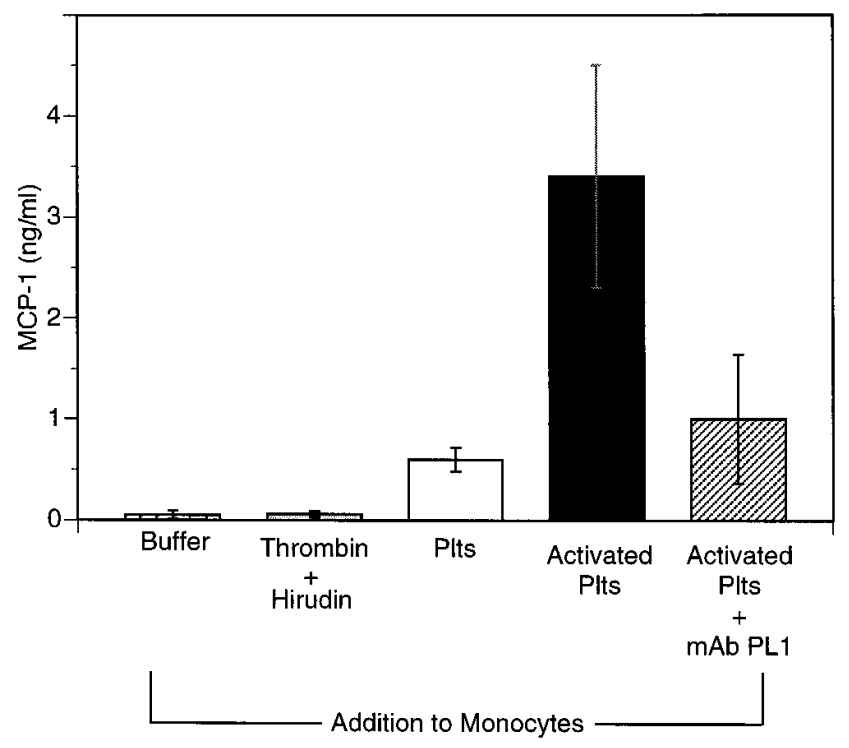

Figure 3. An antibody against PSGL-1 inhibits MCP-1 release by monocytes signaled by activated platelets (Plts). Platelets $\left(10^{8} / \mathrm{ml}\right)$ were activated with thrombin as described in Fig. 1.5 min before mixing activated platelets with monocytes $\left(10^{6} / \mathrm{ml}\right)$, the Fab' fragment of $\mathrm{mAb}$ PL1 $(10 \mu \mathrm{g} / \mathrm{ml})$ was added to the monocyte suspension. After $18 \mathrm{~h}, \mathrm{MCP}-1$ secretion by monocytes was quantitated. The figure represents the mean $\pm \mathrm{SE}$ of three experiments.

taining multiple monocytes formed. These aggregates, and nuclear translocation of p65, were inhibited when mAb G1 (Fig. $4 D$ ) or the Fab' fragment of mAb PL1 (not shown) was added to the cell suspensions. The control antibodies, S12, and PL2 did not attenuate p65 translocation to the nucleus or the formation of platelet-monocyte aggregates (not shown). This demonstrates that cell-cell contact was necessary for NF- $\mathrm{B}$ translocation (Fig. 4), just as for MCP-1 release (Fig. 2). In support of this conclusion, we found that supernatants from activated platelets did not induce NF- $\mathrm{B}$ translocation in monocytes (not shown) or release of MCP-1 $(<0.1 \mathrm{ng} / \mathrm{ml}$; compare to Fig. 1).

$P$-Selectin does not directly induce MCP-1 secretion. The results at this point demonstrated that adhesion via P-selectin was required for platelet-induced generation of MCP-1 by monocytes. To determine if P-selectin was sufficient- that is, if it acted as a signaling molecule that did not require other factors (40)—we examined MCP-1 release from monocytes adherent to purified P-selectin or to transfected cells that express P-selectin. While we previously reported that adhesion of monocytes to P-selectin did not induce chemokine secretion without addition of PAF, it was possible that platelets present P-selectin at higher densities than those we used previously (3). Therefore, P-selectin immunopurified from platelets was immobilized on plastic surfaces in increasing concentrations, and monocyte adhesion and MCP-1 release were measured in parallel. We found that increasing the concentration of P-selectin used to coat the plates above levels required for maximal adhesion did not induce MCP-1 release from the adherent leukocytes (Fig. 5). Similarly, increasing the site densities of $\mathrm{P}$-selectin expressed in $\mathrm{CHO}$ cell lines did not induce MCP-1 secretion by adherent monocytes (not shown). These results are consistent with our previous studies and indicate that, 

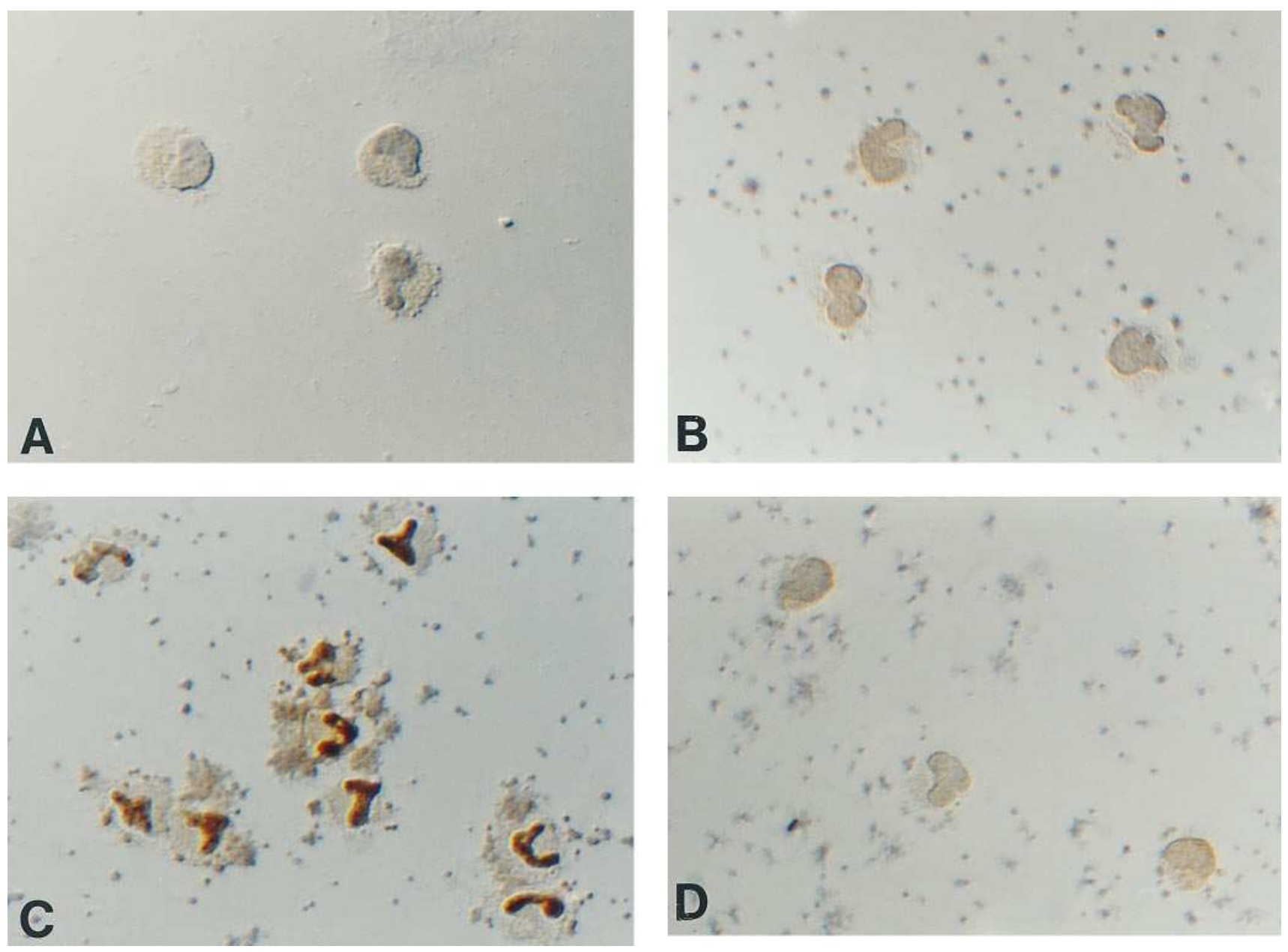

Figure 4. Activated platelets stimulate the translocation of $\mathrm{p} 65$ from the cytoplasm to the nucleus of monocytes. Monocytes were incubated in suspension for $2 \mathrm{~h}$ in the presence of $(A)$ control buffer, $(B)$ inactivated platelets, $(C)$ activated platelets, or $(D)$ activated platelets and the $\mathrm{F}\left(\mathrm{ab}^{\prime}\right)_{2}$ fragment of mAb G1 $(10 \mu \mathrm{g} / \mathrm{ml})$. In parallel incubations, the $\mathrm{F}\left(\mathrm{ab}^{\prime}\right)_{2}$ fragment of $\mathrm{mAb} \mathrm{S12}(10 \mu \mathrm{g} / \mathrm{ml})$ did not inhibit the formation of platelet-monocyte aggregates or nuclear translocation of p65 (not shown). Slides were prepared as described in Methods, and immunolocalization of p65 (brown stain) was examined using light microscopy with Nomarski interference contrast optics. Representative fields from a single experiment are shown. Three additional experiments yielded similar results.

whereas binding of P-selectin to PSGL-1 is a key event when activated platelets induce chemokine secretion by monocytes (Figs. 2 and 3), the platelets must also present one or more signaling molecules to elicit this response.

$P A F$ does not account for signaling of MCP-1 secretion when activated platelets interact with monocytes. PAF, a phospholipid, is synthesized by activated human platelets under some conditions (41). Therefore, we examined the possibility that PAF is the signaling molecule presented by activated platelets. However, we were unable to detect PAF production, either cell associated or secreted, by thrombin-stimulated platelets after $30 \mathrm{~min}$ (not shown). This is consistent with the observation that accumulation of PAF is minimal and transient in activated platelets unless the intracellular degrading enzyme, PAF acetylhydrolase, is first inhibited (41). PAF production was not increased when monocytes were incubated with thrombin-stimulated platelets. We considered the possibility that PAF, which is capable of eliciting biological effects at subnanomolar concentrations, was being synthesized at levels below those detected by our metabolic labeling assay. However, WEB 2086, a specific competitive antagonist for the
PAF receptor, did not inhibit MCP-1 secretion $(1.2 \%$ decrease). Finally, addition of exogenous PAF to platelet-monocyte aggregates augmented release of MCP-1 over that induced by the activated platelets alone (twofold), suggesting that the monocyte PAF receptor had not been desensitized by PAF generated by the platelets.

RANTES is released by activated platelets and regulates MCP-1 secretion by monocytes. RANTES, a CC chemokine that was originally detected in activated T lymphocytes (42), is stored and secreted from platelets stimulated with thrombin (43). There is a cell surface receptor for RANTES on monocytic cells $(8,44)$. Therefore, we explored the role of this chemokine as a platelet-derived signal for monocytes. We found that RANTES was present in substantial amounts in the supernatants from activated platelets $(1.6 \pm 0.6 \mathrm{vs} 16.4 \pm 4.9 \mathrm{ng} /$ $\mathrm{ml}$, platelets and activated platelets, respectively). Further, we found that a neutralizing antibody against RANTES significantly attenuated MCP-1 release in platelet-monocyte suspensions (Fig. 6). An isotype-matched control antibody did not inhibit MCP-1 secretion (not shown). The antibody to RANTES also inhibited nuclear translocation of p65, but did not block 


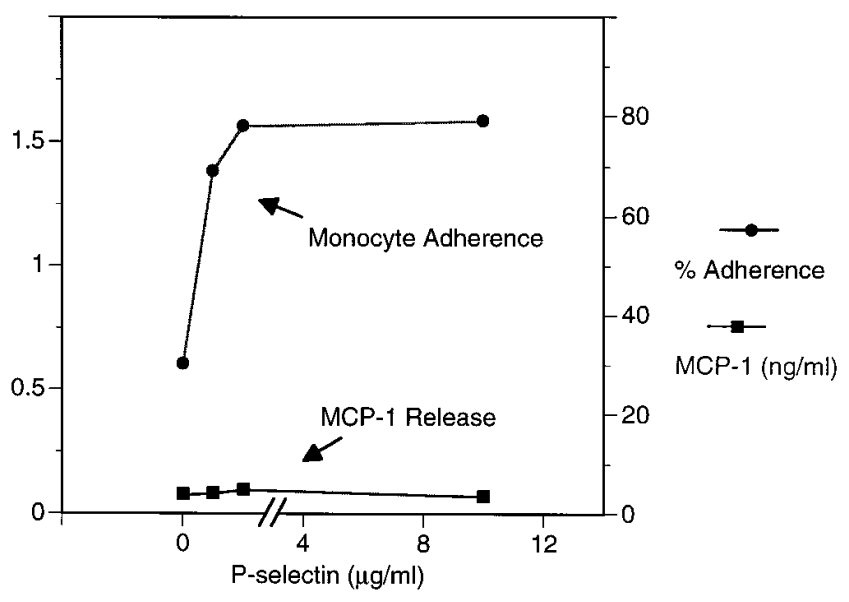

Figure 5. P-Selectin does not induce MCP-1 secretion. Increasing concentrations of purified, immobilized P-selectin from platelets were placed on plastic surfaces, and monocyte adhesion and MCP-1 release were measured after $18 \mathrm{~h}$. This figure is representative of two experiments.

the formation of platelet-monocyte aggregates in activated platelet-monocyte suspensions (not shown). Thus, RANTESinduced signaling is downstream of the binding event.

$P$-Selectin and RANTES act in concert to induce MCP-1 secretion. Although high levels of RANTES were present in the supernatants from thrombin-stimulated platelets, addition of these supernatants did not enhance MCP-1 release by monocytes in suspension $(<0.1 \mathrm{ng} / \mathrm{ml})$. Likewise, recombinant human RANTES (rhRANTES), at concentrations up to $100 \mathrm{ng}$ / $\mathrm{ml}$, had no appreciable effect on MCP-1 production by monocytes in suspension $(0.13 \pm 0.01 \mathrm{ng} / \mathrm{ml})$. Therefore, we asked if $\mathrm{P}$-selectin and RANTES could cooperatively induce MCP-1 secretion. Monocytes were allowed to settle onto plates coated with albumin or P-selectin, rhRANTES was added, and MCP-1 release was measured. RANTES, at concentrations similar to those found in activated platelet supernatants, induced MCP-1 secretion from monocytes incubated on immobilized P-selectin but not those incubated on albumin (Fig. 7). Adhesion of monocytes to fibronectin, a protein that, like albumin, is present on the surface of stimulated platelets (45), did not potentiate MCP-1 release in response to rhRANTES (not shown).

When P-selectin was presented to monocytes on the surface of a heterologous cell, RANTES also induced MCP-1 release. Monocytes adherent to transfected $\mathrm{CHO}$ cells that expressed P-selectin secreted MCP-1 in response to rhRANTES (not shown), but those incubated on wild-type $\mathrm{CHO}$ cells did not. These results indicate that P-selectin and RANTES act in concert to induce MCP-1 release and may be one mechanism by which activated platelets induce monokine synthesis.

Activated platelets induce a specific pattern of responses in monocytes. NF-кB is reported to act cooperatively with other transcription factors (46), and p65 can form homo- or heterodimers that have distinct transcriptional properties $(6,7)$. Therefore, we examined the expression of other gene products besides MCP-1 when activated platelets signal monocytes. We chose IL- 8 and TF, two genes that contain $\kappa$ B-like binding sites in their promoter regions $(47,48)$.

Activated platelets induce IL-8 secretion by monocytes. IL-8, a $\mathrm{C}-\mathrm{X}-\mathrm{C}$ chemokine, is a potent neutrophil chemoattractant

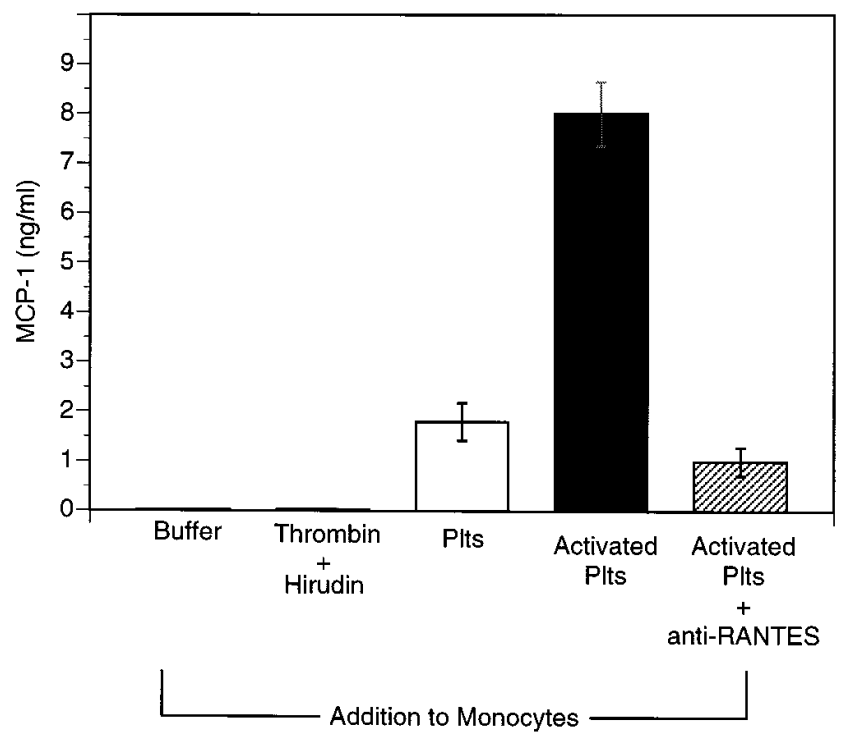

Figure 6. Anti-RANTES blocks MCP-1 release when activated platelets signal monocytes. Monocytes were incubated with platelets in the presence, or absence, of an antibody against RANTES $(40 \mu \mathrm{g} / \mathrm{ml})$ for $18 \mathrm{~h}$. MCP-1 in the conditioned medium was then quantitated by ELISA. This figure represents the mean $\pm \mathrm{SE}$ of five experiments.

released by stimulated monocytes and other cells (49). We found that monocytes alone, or those treated with thrombin neutralized with hirudin, secreted very low levels of IL-8 (Fig. 8 ). The addition of unstimulated platelets increased IL-8 production slightly, similar to small increases that were observed when we measured MCP-1 secretion (Fig. $1 A$ ). In contrast, the addition of activated platelets induced marked increases in IL-8 release (Fig. 8). Increased IL-8 secretion was attenuated or blocked by antibodies directed against P-selectin (Fig. 8) and PSGL-1 (not shown) in five independent experiments.

We found that increased IL-8 secretion was induced when monocytes adherent to purified, immobilized P-selectin were stimulated with rhRANTES (not shown). In contrast, those incubated on control surfaces coated with albumin or fibronectin

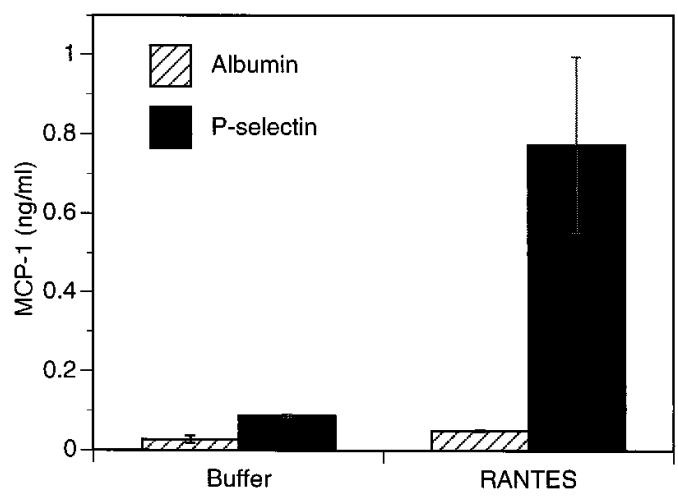

Figure 7. Adhesion of monocytes to immobilized P-selectin enhances MCP-1 secretion in response to RANTES. Monocytes were allowed to adhere to purified, immobilized P-selectin from platelets $(2 \mu \mathrm{g} / \mathrm{ml})$ or albumin $(10 \mu \mathrm{g} / \mathrm{ml})$ in the absence or presence of RANTES (10 $\mathrm{ng} /$ $\mathrm{ml})$. MCP-1 secretion was measured in the cell-free supernatants after $18 \mathrm{~h}$. This figure represents the mean $\pm \mathrm{SE}$ of three experiments. 


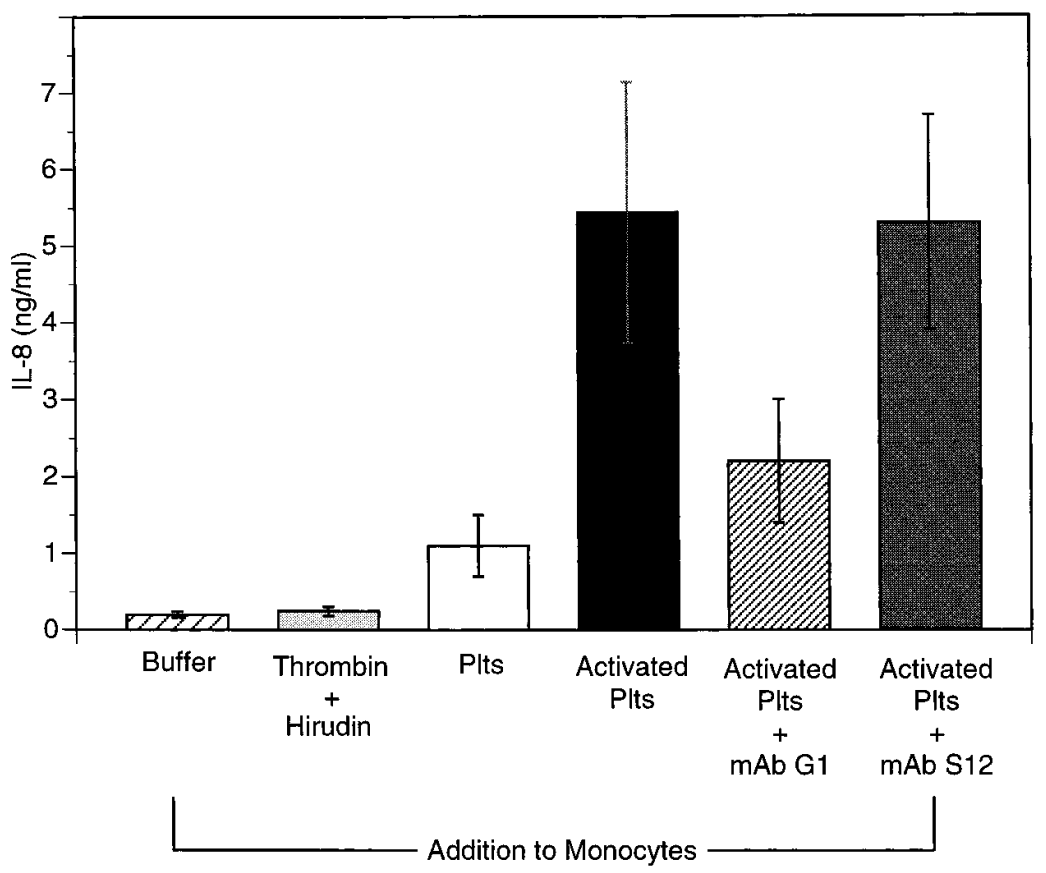

Figure 8. Activated platelets (Plts) enhance IL-8 production by monocytes, and this response is attenuated by neutralizing P-selectin. Monocytes were incubated with platelets as previously described in the presence of buffer, the $\mathrm{F}\left(\mathrm{ab}^{\prime}\right)_{2}$ of $\mathrm{mAb} \mathrm{G} 1(10 \mu \mathrm{g} / \mathrm{ml})$, or the $\mathrm{F}\left(\mathrm{ab}^{\prime}\right)_{2}$ of $\mathrm{mAb}$ S12 $(10 \mu \mathrm{g} / \mathrm{ml})$. After $18 \mathrm{~h}$, IL-8 secretion by monocytes was quantitated. This figure represents the mean $\pm \mathrm{SE}$ of five experiments that showed increased IL- 8 secretion by monocytes exposed to activated platelets. released background levels of the chemokine. Consistent with these results, release of IL-8 into mixtures of monocytes and activated platelets was inhibited by an antibody to RANTES (not shown).

Activated platelets do not elicit TF activity on monocytes. Blood coagulation is initiated through the action of TF, an integral membrane protein that is induced on the surface of activated monocytes in response to LPS (50), certain cytokines $(51,52)$, or immune complexes (53). Using a two-stage amidolytic assay, we found that activated platelets did not induce monocyte TF activity (Fig. 9) even though these cells robustly secreted MCP-1 and IL-8 in parallel (not shown). Although platelets had no effect, LPS significantly $(P<0.05)$ increased TF expression by monocytes, indicating that the leukocytes were responsive to appropriate stimuli (Fig. 9). When TF activity was measured in parallel experiments using a singlestage plasma coagulation assay $(n=3)$ or a single-stage amidolytic assay $(n=6)$, activated platelets did not significantly enhance TF expression. We also found that monocytes adherent to increasing concentrations of purified, immobilized P-selectin did not express increased TF activity after an 18-h incubation compared with activity in cells incubated on albumin (not shown). Similar results were seen with 4- and 8-h incubations. The addition of rhRANTES (up to $100 \mathrm{ng} / \mathrm{ml}$ ) did not enhance surface TF activity on monocytes (not shown).

\section{Discussion}

In this report we describe a tethering and signaling system in which adhesion of activated platelets to monocytes induces nuclear translocation of NF-кB and secretion of MCP-1, a chemokine that requires NF-кB for its synthesis (39). Binding of P-selectin on the platelet to PSGL-1 on the monocyte is required for MCP-1 secretion. This molecular interaction mediates rapid, stable adhesion between the two cells (13). However, it is not sufficient to induce chemokine secretion, as shown by experiments in which monocyte adhesion to purified
$\mathrm{P}$-selectin or to $\mathrm{P}$-selectin transfectants failed to trigger release of MCP-1. This finding indicates that one or more signaling molecules is required. In these respects, the interaction between activated platelets and monocytes resembles leukocyte-endothelial cell interactions, where distinct tethering and signaling factors are involved $(1,5,54)$. In the tethering and signaling interaction between platelets and monocytes, RANTES, which is stored in platelet secretory vesicles and released upon cellular activation (43), provides a critical signal for MCP-1 generation by the leukocytes. P-Selectin binding to PSGL-1 may facilitate monocyte activation not only by mediating close cell-to-cell contact but also by modifying intracellular signals triggered through the receptor for RANTES. Monocyte interactions with ECM, where ligation of surface integrins initiates tran-

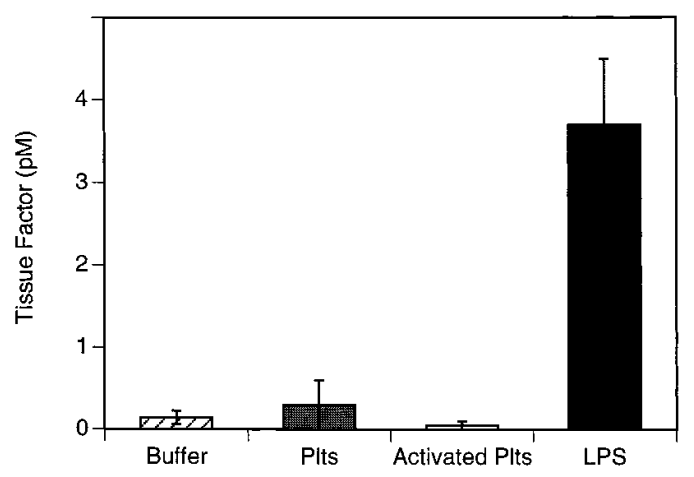

Figure 9. Activated platelets (Plts) do not induce TF activity on the surface of monocytes. Monocytes were incubated with buffer, platelets, activated platelets, or LPS $(100 \mathrm{ng} / \mathrm{ml})$ as described in Fig. 1. After $18 \mathrm{~h}$, TF activity was measured using the two-stage amidolytic assay (30). The data are expressed as activity equivalent to $x \mathrm{pM}$ of purified TF. This figure represents the mean \pm SE of three independent experiments. 
scription of IE genes but the action of a signaling molecule is required for full synthesis and release, has similar features (4).

Several studies, in addition to our current experiments, demonstrate that platelets activated by thrombin avidly adhere to leukocytes via P-selectin $(10,26,55)$. As in stimulated endothelial cells, P-selectin is translocated from intracellular granules to the plasma membranes of stimulated platelets $(26$, $35,56)$. In contrast to stimulated endothelial cells, where thrombin elicits transient expression of P-selectin $(1,23,57)$, stimulated platelets express P-selectin on their surface for several hours $(58,59)$. Moreover, the surface density of P-selectin on platelets is higher than its density on endothelial cells (35, 55-57). These features may enable platelets to adhere to effector leukocytes for prolonged periods at sites of inflammation or thrombosis (13).

P-Selectin presented by platelets not only mediates cellcell contact but modifies, and may directly induce, functional responses in leukocytes. Nagata and co-workers $(60,61)$ reported that thrombin-stimulated platelets cause superoxide anion generation by neutrophils and monocytes, and Yeo et al. (55) found that neutrophils shed L-selectin, upregulate MAC-1 $\left(\alpha_{M} / \beta_{2}\right.$ integrin), and polarize when they adhere to activated platelets. In these reports the leukocyte responses were inhibited by antibodies directed against P-selectin, but the experiments did not examine the possibility that other factors expressed by activated platelets signal the responses and that tethering by P-selectin is necessary, but not sufficient, for the signaling. Our previous studies examining the effects of purified P-selectin on activation responses of neutrophils (62-64) and monocytes $(3,12)$, together with our current observations, indicate that the latter mechanism is more likely. We found that activated platelets induce MCP-1 secretion by monocytes through mechanisms that involve interactions between P-selectin and its critical ligand, PSGL-1. However, P-selectin did not directly induce MCP-1 secretion, indicating that other factors were involved. We evaluated PAF, which was a likely candidate based on our earlier experiments (3), as the plateletderived signaling molecule. However, we did not find evidence for its participation under the conditions of these experiments. Instead, our experiments indicated that critical signals are delivered by RANTES. RANTES was released from platelets stimulated with thrombin and induced chemokine secretion from monocytes adherent to purified P-selectin. RANTES is known to be a chemoattractant for monocytes $(65,66)$ and to stimulate $\left[\mathrm{Ca}^{2+}\right]_{\mathrm{i}}$ transients in these cells (67). High concentrations of RANTES $(1 \mu \mathrm{M})$ can also induce IL-2 and IL-5 production by lymphocytes (68). However, RANTES was not previously known as an agonist for chemokine gene expression in monocytes. It is possible that it induces this response only under restricted conditions and that adhesion to P-selectin is one of these; platelet supernatants containing RANTES did not induce chemokine secretion from monocytes in suspension, and rhRANTES, at concentrations similar to those found in platelet supernatants $(1-10 \mathrm{nM})$, failed to induce chemokine release from monocytes incubated on control surfaces. While RANTES is secreted from activated platelets and may have acted in solution, it is also possible that some of the secreted factor associated with the surfaces of the platelets and activated the monocytes in a juxtacrine fashion similar to PAF-induced responses at the surface of endothelial cells. Other chemokines, such as platelet factor 4, bind to proteoglycans isolated from human platelets (69). Recent evidence also indicates that RANTES binds to cellular surfaces (66), consistent with the notion that chemokines may act as juxtacrine signals when localized by this mechanism (for review see reference 40).

Our finding that RANTES robustly stimulated monocytes that were adherent to P-selectin but not when they were adherent to control surfaces is similar to our earlier result with PAF (3). The receptors for RANTES and PAF are both members of the serpentine G-protein-linked family (8), suggesting that engagement of PSGL-1 on monocytes specifically influences intracellular pathways linked to receptors of this class. The mechanisms of such intracellular integration $(3,54)$ are as yet unknown. It is also unknown whether potentiation of signaling occurs through other classes of receptors.

The synthesis and secretion of certain chemokines and other IE gene products is influenced by the NF-кB/Rel family of transcription factors $(6,7,70)$. Little is known about $\mathrm{NF} \leftarrow \mathrm{B}$ regulation when cells adhere to one another. LalmanachGirard et al. (71) found that activated, fixed $\mathrm{T}$ cells induced $\mathrm{NF}-\kappa \mathrm{B}$ activity in the nucleus of B cells using electromobility shift assays. Here we show that specific adhesive interactions between living cells cause nuclear localization of Rel proteins. We found that monocytes, alone or incubated with resting platelets, had little detectable p65 in their nucleus. In contrast, monocytes adherent to activated platelets had robust nuclear immunolocalization of p65. Neutralization of P-selectin or PSGL-1 inhibited platelet-monocyte aggregation and nuclear translocation of p65. These maneuvers also inhibited secretion of $\mathrm{MCP}-1$, which contains a prototypic $\kappa \mathrm{B}$ recognition sequence for p50-p65 (39). However, when we examined two other factors that are coded for by genes with $\kappa \mathrm{B}$-regulatory sequences, IL-8 and TF $(47,72)$, only IL-8 was generated. Like $\mathrm{TF}$, we also found that another NF-кB dependent gene, TNF- $\alpha$, was not induced in monocytes by activated platelets. This indicates that there is differential expression of Rel-responsive gene products when activated platelets signal monocytes. One way in which activation of specific genes targeted by Rel transcription factors may be accomplished is by preferential binding of individual Rel heterodimers to specific $\kappa \mathrm{B}$ sequences $(47,73)$. For example, p65 can pair with cRel, another family member, to form a potent transacting factor with effects different from p50-p65 complexes $(6,7)$. Our immunocytochemical assay does not distinguish between translocation of cRel-p65 and p50-p65 since we used an antibody to the p65 subunit. However, both TF and IL- 8 have $\kappa \mathrm{B}$ sequences in their regulatory regions that favor binding of cRel-p65 $(47,72)$, so this feature alone does not account for differential expression of IL-8 vs TF in our experiments. We are currently exploring other mechanisms, both transcriptional and translational, that may be involved when adherent monocytes are stimulated by signaling molecules such as RANTES. The combinatorial effects of activation through specific surface receptors for these factors, and signal modification by adhesion to P-selectin, may be key regulatory mechanisms leading to particular patterns of gene expression. Variations in combinatorial signaling may also account for the differences in our findings and those of Celi et al. (74), who reported that P-selectin enhances TF expression by monocytes under some conditions. However, even in that report the increase of TF expression induced by P-selectin was very modest relative to the level induced by LPS, a strong signal for its induction.

P-Selectin likely has complex roles in inflammatory syndromes where leukocytes adhere to activated platelets. Using 
a vascular shunt model to study thrombosis, Palabrica et al. (21) demonstrated that neutralization of P-selectin inhibits leukocyte accumulation and fibrin deposition in the shunt. OxLDL and cigarette smoke, two factors that accelerate the development of evolving atherosclerotic lesions (70), also enhance platelet-leukocyte interactions. These interactions are inhibited by blocking P-selectin $(19,20)$. Our results indicate that P-selectin, expressed on the surface of platelets, can regulate chemokine synthesis by monocytes in concert with RANTES, a preformed chemokine not previously known to induce cytokine synthesis. In specific situations, P-selectin may cooperate with other platelet-signaling factors to alter leukocyte function (75). Indeed, platelet-released fibrinogen can bridge GPIIb/ IIIa on platelets with CD11c/CD18 on neutrophils, an interaction that generates a neutrophil oxidative burst (76). This process requires adhesion via $\mathrm{P}$-selectin, further indicating that $\mathrm{P}$-selectin may act in concert with platelet-signaling factors (75) and with other adhesion molecules $(75,77,78)$ to elicit unique patterns of gene expression at sites of inflammation.

\section{Acknowledgments}

We thank Kurt Albertine and Nancy Chandler (University of Utah Health Sciences Center Research Microscopy Facility) for helpful discussions regarding microscopy techniques; Donelle Benson, Sue Cowley, Ruth Ann Green, Angela Le, and Margaret Vogel for excellent technical assistance; and Michelle Bills for preparation of the manuscript. We also appreciate preparation of the $\mathrm{CHO}$ cells expressing different levels of P-selectin by Kamala Patel, and the generous gift of reagents from John Grayeb (Centocor Inc.).

This work was supported by the Nora Eccles Treadwell Foundation and by individual grants from the National Institutes of Health (HL44525 to G.A. Zimmerman, HL45510 to R.P. McEver, and AI30735 to M.R. Elstad), Department of Veteran Affairs Medical Research Funds (M.R. Elstad), and a training grant (HL07636) and a Center of Excellence in Molecular Hematology (DK49210) supported by the National Institutes of Health.

\section{References}

1. Zimmerman, G.A., S.M. Prescott, and T.M. McIntyre. 1992. Endothelial cell interactions with granulocytes: tethering and signaling molecules. Immunol. Today. 13:93-100.

2. Rosales, C., and R.L. Juliano. 1995. Signal transduction by cell adhesion receptors in leukocytes. J. Leukocyte Biol. 57:189-198.

3. Weyrich, A.S., T.M. McIntyre, R.P. McEver, S.M. Prescott, and G.A. Zimmerman. 1995. Monocyte tethering by P-selectin regulates monocyte chemotactic protein-1 and tumor necrosis factor- $\alpha$ secretion: signal integration and NF-кB translocation. J. Clin. Invest. 95:2297-2303.

4. Juliano, R.L., and S. Haskill. 1993. Signal transduction from the extracellular matrix. J. Cell Biol. 120:577-585.

5. McEver, R.P., K.L. Moore, and R.D. Cummings. 1995. Leukocyte trafficking mediated by selectin-carbohydrate interactions. J. Biol. Chem. 270: 11025-11028.

6. Siebenlist, U., G. Franzoso, and K. Brown. 1994. Structure, regulation and function of NF-кB. Annu. Rev. Cell Biol. 10:405-455.

7. Baeuerle, P.A., and T. Henkel. 1994. Function and activation of NF-кB in the immune system. Annu. Rev. Immunol. 12:141-179.

8. Murphy, P.M. 1994. The molecular biology of leukocyte chemoattractant receptors. Annu. Rev. Immunol. 12:593-633.

9. Kravchenko, V.V., P. Zhixing, J. Han, J.-M. Herbert, R.J. Ulevitch, and R.D. Ye. 1995. Platelet-activating factor induces NF-кB activation through a $\mathrm{G}$ protein-coupled pathway. J. Biol. Chem. 270:14928-14934.

10. Larson, E., A. Celi, G.E. Gilbert, B.C. Furie, J.K. Erban, R. Bonfanti, D.D. Wagner, and B. Furie. 1989. PADGEM protein: a receptor that mediated the interaction of activated platelets with neutrophils and monocytes. Cell. 59:305-312.

11. McEver, R.P. 1994. Selectins. Curr. Opin. Immunol. 6:75-84.

12. Elstad, M.R., T.M. McIntyre, S.M. Prescott, and G.A. Zimmerman. 1995. The interaction of leukocytes with platelets in blood coagulation. Curr. Opin. Hematol. 2:47-54.
13. Rinder, H.M., J.L. Tracey, C.S. Rinder, D. Leitenberg, and B.R. Smith. 1994. Neutrophil but not monocyte activation inhibits P-selectin-mediated platelet adhesion. Thromb. Haemostasis. 71:750-756.

14. Sako, D., X.-J. Chang, K.M. Barone, G. Vachino, H.M. White, G. Shaw, G.M. Veldman, K.M. Bean, T.J. Ahern, B. Furie, et al. 1993. Expression cloning of a functional glycoprotein ligand for P-selectin. Cell. 75:1179-1186.

15. Moore, K.L., N.L. Stults, S. Diaz, D.F. Smith, R.D. Cummings, A. Varki, and R.P. McEver. 1992. Identification of a specific glycoprotein ligand for P-selectin (CD62) on myeloid cells. J. Cell Biol. 118:445-456.

16. Moore, K.L., K.D. Patel, R.E. Bruehl, L. Fugang, D.A. Johnson, H.S. Lichenstein, R.D. Cummings, D.F. Bainton, and R.P. McEver. 1995. P-selectin glycoprotein ligand-1 mediates rolling of human neutrophils on P-selectin. $J$. Cell Biol. 128:661-671.

17. Wester, J., J.J. Sixma, J.J. Geuze, and H.F.G. Heijnen. 1979. Morphology of the hemostatic plug in human skin wounds. Transformation of the plug. Lab. Invest. 41:182-192.

18. Munro, J.M., and R.S. Cotran. 1988. Biology of disease. The pathogenesis of atherosclerosis: atherogenesis and inflammation. Lab. Invest. 58:249-261.

19. Lehr, H.-A., A.M. Ologsson, T.E. Carew, P. Vajkoczy, U.H. von Andrian, C. Hubner, M.C. Berndt, D. Steinberg, K. Messmer, and K.-E. Arfors. 1994. P-selectin mediates the interaction of circulating leukocytes with platelets and microvascular endothelium in response to oxidized lipoprotein in vivo. Lab. Invest. 71:380-386.

20. Lehr, H.-A., B. Frei, and K.-E. Arfors. 1994. Vitamin C prevents cigarette smoke-induced leukocyte aggregation and adhesion to endothelium in vivo. Proc. Natl. Acad. Sci. USA. 91:7688-7692.

21. Palabrica, T., R. Lobb, B.C. Furie, M. Aronovitz, C. Benjamin, Y.-M Hsu, S.A. Sajer, and B. Furie. 1992. Leukocyte accumulation promoting fibrin deposition is mediated in vivo by P-selectin on adherent platelets. Nature (Lond.). 359:848-851.

22. Ushiyama, S., T.M. Laue, K.L. Moore, H.P. Erickson, and R.P. McEver. 1993. Structural and functional characterization of monomeric soluble P-selectin and comparison with membrane P-selectin. J. Biol. Chem. 268:15229-15237.

23. Geng, J.-G., M.P. Bevilacqua, K.L. Moore, T.M. McIntyre, S.M. Prescott, J.M. Kim, G.A. Bliss, G.A. Zimmerman, and R.P. McEver. 1990. Rapid neutrophil adhesion to activated endothelium mediated by GMP-140. Nature (Lond.). 343:757-760

24. Morrissey, J.H., D. Revak, P. Tejada, D.S. Fair, and T.S. Edgington. 1988. Resolution of monomeric and heterodimeric forms of tissue factor, the high-affinity cellular receptor for factor VII. Thromb. Res. 50:481-493.

25. Elstad, M.R., S.M. Prescott, T.M. McIntyre, and G.A. Zimmerman. 1988. Synthesis and release of platelet-activating factor by stimulated human mononuclear phagocytes. J. Immunol. 140:1618-1624.

26. Hamburger, S.A., and R.P. McEver. 1990. GMP-140 mediates adhesion of stimulated platelets to neutrophils. Blood. 75:550-554.

27. Prescott, S.M., A.R. Seeger, G.A. Zimmerman, T.M. McIntyre, and J.M. Maraganore. 1990. Hirudin-based peptides block the inflammatory effects of thrombin on endothelial cells. J. Biol. Chem. 265:9614-9616.

28. Elstad, M.R., F.S. Cowley, T.R. LaPine, R.P. McEver, T.M. McIntyre, S.M. Prescott, and G.A. Zimmerman. 1995. P-selectin regulates platelet-activating factor synthesis and phagocytosis by monocytes. J. Immunol. 155:21092122.

29. Disdier, M., J.H. Morrissey, R.D. Fugate, D.F. Bainton, and R.P. McEver. 1992. Cytoplasmic domain of P-selectin (CD62) contains the signal for sorting into the regulated secretory pathway. Mol. Biol. Cell. 3:309-321.

30. Drake, T.A., R. Wolfram, J.H. Morrissey, and T.S. Edgington. 1989. Functional tissue factor is entirely cell surface expressed on lipopolysaccharidestimulated human blood monocytes and a constitutively tissue factor-producing neoplastic cell line. J. Cell Biol. 109:389-395.

31. Faucette, K.J., C.J. Parker, T. McCluskey, N.J. Bernshaw, and G.M. Rodgers. 1992. Induction of tissue factor activity in endothelial cells and monocytes by a modified form of albumin present in normal human plasma. Blood. 79:2888-2895

32. Gregory, S.A., R.S. Kornbluth, H. Helin, H.G. Remold, and T.S. Edgington. 1986. Monocyte procoagulant inducing factor: a lymphokine involved in the $\mathrm{T}$ cell-instructed monocyte procoagulant response to antigen. J. Immunol. 137:3231-3239.

33. Colotta, F., F.L. Sciacca, M. Sironi, W. Luini, M.J. Rabiet, and A. Mantovani. 1994. Expression of monocyte chemotactic protein-1 by monocytes and endothelial cells exposed to thrombin. Am. J. Pathol. 144:975-985.

34. Rinder, H.M., E.L. Snyder, J.L. Bonan, P.A. Napychank, H. Malkus, and B.R. Smith. 1993. Activation in stored platelet concentrates: correlation between membrane expression of P-selectin, glycoprotein IIb/IIIa, and betathromboglobulin release. Transfusion (Bethesda). 33:25-29.

35. McEver, R.P., and M.N. Martin. 1984. A monoclonal antibody to a membrane glycoprotein binds only to activated platelets. J. Biol. Chem. 259: 9799-9804.

36. Foxall, C., S.R. Watson, D. Dowbenko, C. Fennie, L.A. Lasky, M. Kiso, A. Hasegawa, D. Asa, and B.K. Brandley. 1992. The three members of the selectin receptor family recognize a common carbohydrate epitope, the sialyl lewis ${ }^{\mathrm{x}}$ oligosaccharide. J. Cell Biol. 117:895-902.

37. Varki, A. 1994. Selectin ligands. Proc. Natl. Acad. Sci. USA. 91:7390-7397. 
38. Norgard, K.E., K.L. Moore, S. Diaz, N.L. Stults, S. Ushiyama, R.P. McEver, R.D. Cummings, and A. Varki. 1993. Characterization of a specific ligand for P-selectin on myeloid cells. J. Biol. Chem. 268:12764-12774.

39. Ueda, A., K. Okuda, S. Ohno, A. Shirai, T. Igarashi, K. Matsunaga, J. Fukushima, S. Kawamoto, Y. Ishigatsubo, and T. Okubo. 1994. NF-кB and Sp1 regulate transcription of the human chemoattractant protein-1 gene. J. Immunol. 153:2052-2063.

40. Zimmerman, G.A., D.E. Lorant, T.M. McIntyre, and S.M. Prescott. 1993. Juxtacrine intercellular signaling: another way to do it. Am. J. Respir. Cell Mol. Biol. 9:573-577.

41. Touqui, L., M. Hatmi, and B.B. Vargaftig. 1985. Human platelets stimulated by thrombin produce platelet-activating factor (1-0-alkyl-2-acetyl-sn-glycero-3-phosphocholine) when the degrading enzyme acetyl hydrolase is blocked. Biochem. J. 229:811-816.

42. Schall, T.J., J. Jongstra, B.J. Dyer, J. Jorgensen, C. Claylberger, M.M. Davis, and A.M. Krensky. 1988. A human T cell-specific molecule is a member of a new gene family. J. Immunol. 141:1018-1025.

43. Kameyoshi, Y., A. Dorschner, A.I. Mallet, E. Christophers, and J.-M. Schroder. 1992. Cytokine RANTES released by thrombin-stimulated platelets is a potent attractant for human eosinophils. J. Exp. Med. 176:587-592.

44. Ming Wang, J., D.W. McVicar, J.J. Oppenheim, and D.J. Kelvin. 1993. Identification of RANTES receptors on human monocytic cells: competition for binding and desensitization by homologous chemotactic cytokines. J. Exp. Med. 177:699-705.

45. Packham, M.A. 1994. Role of platelets in thrombosis and hemostasis. Can. J. Physiol. Pharmacol. 72:278-284.

46. Stein, B., and A.S. Baldwin, Jr. 1993. Distinct mechanisms for regulation of the interleukin- 8 gene involve synergism and cooperativity between C/EBP and NF-кB. Mol. Cell. Biol. 13:7191-7198.

47. Kunsch, C., and C.A. Rosen. 1993. NF-кB subunit-specific regulation of the interleukin-8 promoter. Mol. Cell. Biol. 13:6137-6146.

48. Oeth, P.A., G.C.N. Parry, C. Kunsch, P. Nantermet, C.A. Rosen, and N. Mackman. 1994. Lipopolysaccharide induction of tissue factor gene expression in monocytic cells is mediated by binding of $\mathrm{c}-\mathrm{Rel} / \mathrm{p} 65$ heterodimers to a $\mathrm{\kappa B}$ like site. Mol. Cell. Biol. 14:3772-3781.

49. Baggiolini, M., B. Dewald, and B. Moser. 1994. Interleukin-8 and related chemotactic cytokines-CXC and CC chemokines. Adv. Immunol. 55:97179.

50. Colucci, M., G. Balconi, R. Lorenzet, A. Pietra, D. Locati, M.B. Donati, and N. Semeraro. 1983. Cultured human endothelial cells generate tissue factor in response to endotoxin. J. Clin. Invest. 71:1893-1896.

51. Bevilacqua, M.P., J.S. Pober, G.R. Majeau, R.S. Cotran, and M.A. Gimbrone. 1984. Interleukin 1 (IL-1) induces the biosynthesis and cell surface expression of procoagulant activity in human vascular endothelial cells. J. Exp. Med. 160:618-623.

52. Nawroth, P.P., and D.M. Stern. 1986. Modulation of endothelial cell hemostatic properties by tumor necrosis factor. J. Exp. Med. 163:740-745.

53. Rothberger, H., T.S. Zimmermann, H.L. Spielberg, and J.H. Vaughn. 1977. Leukocyte procoagulant activity: enhancement of production in vivo by IgG and antigen-antibody complexes. J. Clin. Invest. 59:549-557.

54. Zimmerman, G.A., T.M. McIntyre, and S.M. Prescott. 1996. Cell-to-cell communication. In The Lung: Scientific Foundations. 2nd ed. R.G. Crystal, J.B. West, E.R. Weibel, and P.J. Barnes, editors. Raven Press, New York.

55. Yeo, E.L., J.I. Sheppard, and I.A. Feuerstein. 1994. Role of P-selectin and leukocyte activation in polymorphonuclear cell adhesion to surface adherent activated platelets under physiologic shear conditions (an injury vessel wall model). Blood. 83:2498-2507.

56. Hsu-Lin, S.C., C.L. Berman, B.C. Furie, D. August, and B. Furie. 1984. A platelet membrane protein expressed during platelet activation and secretion. J. Biol. Chem. 259:9121-9126.

57. Hattori, R., K.K. Hamilton, R.D. Fugate, R.P. McEver, and P.J. Sims. 1989. Stimulated secretion of endothelial von Willebrand factor is accompanied by rapid redistribution to the cell surface of the intracellular granule membrane protein GMP-140. J. Biol. Chem. 264:7768-7771.

58. George, J.N., E.B. Pickett, S. Saucerman, R.P. McEver, T.J. Kunicki, N. Kieffer, and P.J. Newman. 1986. Platelet surface glycoproteins. Studies on rest- ing and activated platelets and platelet membrane microparticles in normal subjects, and observations in patients during adult respiratory distress syndrome and cardiac surgery. J. Clin. Invest. 78:340-348.

59. Yeo, E.L., C. Gemmell, and M.L. Rand. 1992. In vitro stability of P-selectin expression on human platelets. Blood. 56a. (Abstr.)

60. Nagata, K., T. Tsuji, N. Todoroki, Y. Katagiri, K. Tanoue, H. Yamazaki, N. Hanai, and T. Irimura. 1993. Activated platelets induce superoxide anion release by monocytes and neutrophils through P-selectin (CD62). J. Immunol. 151:3267-3273.

61. Nagata, K., T. Tsuji, N. Hanai, and T. Irimura. 1994. Role of O-linked carbohydrate chains on leukocyte cell membranes in platelet-induced leukocyte activation. J. Biol. Chem. 269:23290-23295.

62. Lorant, D.E., K.D. Patel, T.M. McIntyre, R.P. McEver, S.M. Prescott, and G.A. Zimmerman. 1991. Coexpression of GMP-140 and PAF by endothelium stimulated by histamine or thrombin: a juxtacrine system for adhesion and activation of neutrophils. J. Cell Biol. 115:223-234.

63. Lorant, D.E., M.K. Topham, R.E. Whatley, R.P. McEver, T.M. McIntyre, S.M. Prescott, and G.A. Zimmerman. 1993. Inflammatory roles of P-selectin. J. Clin. Invest. 92:559-570.

64. Lorant, D.E., R.P. McEver, T.M. McIntyre, K.L. Moore, S.M. Prescott, and G.A. Zimmerman. 1995. Activation of polymorphonuclear leukocytes reduces their adhesion to P-selectin and causes redistribution of ligands for P-selectin on their surfaces. J. Clin. Invest. 96:171-182.

65. Schall, T.J., K. Bacon, K.J. Toy, and D.V. Goeddel. 1990. Selective attraction of monocytes and $\mathrm{T}$ lymphocytes of the memory phenotype by cytokine RANTES. Nature (Lond.). 347:669-671.

66. Wiedermann, C.J., E. Kowald, N. Reinisch, C.M. Kaelhler, I. von Luettichau, J.M. Pattison, P. Huie, R.K. Sibley, P.J. Nelson, and A.M. Krensky. 1993. Monocyte haptotaxis induced by the RANTES chemokine. Curr. Biol. 3: $735-739$.

67. Bischoff, S.C., M. Krieger, T. Brunner, A. Rot, V. von Tscharner, M. Baggiolini, and C.A. Dahinden. 1993. RANTES and related chemokines activate human basophil granulocytes through different $\mathrm{G}$ protein-coupled receptors. Eur. J. Immunol. 23:761-767.

68. Bacon, K.B., B.A. Premack, P. Gardner, and T.J. Schall. 1995. Activation of dual T cell signaling pathways by the chemokine RANTES. Science (Wash. DC). 269:1727-1730.

69. Levine, S.P., L.K. Knieriem, and M.A. Rager. 1990. Platelet factor 4 and the platelet secreted proteoglycan: immunologic characterization by crossed immunoelectrophoresis. Blood. 75:902-910.

70. Collins, T. 1993. Biology of disease. Endothelial nuclear factor-кB and the initiation of the atherosclerotic lesion. Lab. Invest. 68:499-507.

71. Lalmanach-Girard, A.-C., T.C. Chiles, D.C. Parker, and T.L. Rothstein 1993. T cell-dependent induction of NF-кB in B cells. J. Exp. Med. 177:12151219.

72. Parry, G.C.N., and N. Mackman. 1994. A set of inducible genes expressed by activated human monocytic and endothelial cells contain $\kappa \mathrm{B}$-like sites that specifically bind c-Rel-p65 heterodimers. J. Biol. Chem. 269:2082320825.

73. Hansen, S.K., P.A., Baeuerle, and F. Blasi. 1994. Purification, reconstitution, and I kappa B association of the c-Rel-p65 (Rel A) complex, a strong activator of transcription. Mol. Cell. Biol. 14:2593-2603.

74. Celi, A., G. Pellegrini, R. Lorenzet, A. De Blasi, N. Ready, B.C. Furie, and B. Furie. 1994. P-selectin induces the expression of tissue factor on monocytes. Proc. Natl. Acad. Sci. USA. 91:8767-8771.

75. Weksler, B.B. 1992. Platelets. In Inflammation: Basic Principles and Clinical Correlates. 2nd ed. J.I. Gallin, I.M. Goldstein, and R. Snyderman, editors. Raven Press, Ltd., New York. 727-746.

76. Ruf, A., and H. Patscheke. 1995. Platelet-induced neutrophil activation: platelet-expressed fibrinogen induces the oxidative burst in neutrophils by an interaction with CD11c/CD18. Br. J. Haematol. 90:792-796.

77. Diacovo, T.G., A.R. deFougerolles, D.F. Bainton, and T.A. Springer. 1994. A functional integrin ligand on the surface of platelets: intercellular adhesion molecule-2. J. Clin. Invest. 94:1243-1251.

78. Kieffer, N., and D.R. Phillips. 1990. Platelet membrane glycoproteins: functions in cellular interactions. Annu. Rev. Cell Biol. 6:329-357. 